Article

\title{
Olefin oligomerization via new and efficient Brönsted acidic ionic liquid catalyst systems
}

\author{
Guoqin Wang a,b, Heyuan Song a,b, Ruiyun Li a,b, Zhen Li a, Jing Chen a,* \\ a State Key Laboratory for Oxo Synthesis and Selective Oxidation, Lanzhou Institute of Chemical Physics, Chinese Academy of Sciences, Lanzhou 730000, \\ Gansu, China \\ b University of Chinese Academy of Sciences, Beijing 100049, China
}

\section{A R T I C L E I N F}

\section{Article history:}

Received 28 December 2017

Accepted 11 April 2018

Published 5 June 2018

\section{Keywords:}

Brönsted acidic ionic liquid

Olefin

Oligomerization

Catalysis

Co-catalyst

\begin{abstract}
A B S T R A C T
Olefin oligomerization reaction catalyzed by new catalyst systems (a Brönsted-acidic ionic liquid as the main catalyst and tricaprylylmethylammonium chloride as the co-catalyst) has been investigated. The synthesized Brönsted acidic ionic liquids were characterized by Fourier transform infrared spectroscopy (FT-IR), ultraviolet-visible spectroscopy (UV), ${ }^{1} \mathrm{H}$ nuclear magnetic resonance (NMR), and ${ }^{13} \mathrm{C}$ NMR to analyze their structures and acidities. The influence of different ionic liquids, ionic liquid loading, different co-catalysts, catalyst ratios (mole ratio of ionic liquid to co-catalyst), reaction time, pressure, temperature, solvent, source of reactants, and the recycling of catalyst systems was studied. Among the synthesized ionic liquids, 1-(4-sulfonic acid)butyl-3-hexylimidazolium hydrogen sulfate ([HIMBs] $\mathrm{HSO}_{4}$ ) exhibited the best catalytic activity under the tested reaction conditions. The conversion of isobutene and selectivity of trimers were $83.21 \%$ and $35.80 \%$, respectively, at the optimum reaction conditions. Furthermore, the catalyst system can be easily separated and reused; a feasible reaction mechanism is proposed on the basis of the distribution of experimental products.
\end{abstract}

(C) 2018, Dalian Institute of Chemical Physics, Chinese Academy of Sciences. Published by Elsevier B.V. All rights reserved.

\section{Introduction}

It is well known that the oligomerization of light olefins to higher oligomers is one of the most important areas in chemical industry and academia. Olefins, especially ethylene, propylene, and butene are the basic materials of the petrochemical industry [1]. The main products of these light olefins, heavier olefins, are valuable building blocks for a range of useful products such as additives, lubricants, comonomers, surfactants, and many other useful chemical products [2-4].

The catalytic oligomerization of light olefins has gained great interest over the past several decades. In order to be more efficient in the oligomerization reaction, a great number of homogeneous and heterogeneous catalyst systems were developed, including liquid acids, solid phosphoric acid (SPA) [5], large-pore zeolites [6-8], montmorillonite clays [9], ion exchange resins [10], Nickel catalysts [11-13], and ionic liquids (ILs) [14-17]. However, most liquid acid catalysts are not eco-friendly because of their strong corrosive character. Solid acid catalysts face drawbacks of rapid deactivation, poor controllability in product distribution, and uneven acidic sites as well as complex waste treatment problems. Although ion-exchange resins perform well, they are not thermally stable and can be easily fouled. Therefore, it is very desirable to develop environmentally benign catalysts for the oligomerization of light olefins.

\footnotetext{
* Corresponding author. Tel: +86-931-4968068; Fax: +86-931-4968129; E-mail: chenj@licp.cas.cn This work was supported by the National Natural Science Foundation of China (21473225). 
Ionic liquid catalysts have received a great deal of attention in the recent past because of their good physicochemical properties, such as low vapor pressure, excellent thermal stability, good structural designability, easy separation from products, and almost complete recyclability [18-25]. According to several reports, a chloroaluminate ionic liquid was successfully used as the catalyst for olefin oligomerization and other reactions [26-31]. Nevertheless, chloroaluminate ILs are very sensitive to air and water, which limits their extensive application $[32,33]$. Hence, it is necessary to develop more stable and efficient non-chloroaluminate acidic ILs.

Owing to the good designability of ionic liquids, we can develop task-specific ionic liquids with special properties according to the given reaction. A typical example are the Brönsted acid ionic liquids, in which an alkane sulfonic acid group is covalently tethered to the IL cation $[34,35]$. These series of functional ionic liquids exhibit remarkable properties compared to conventional homogenous and heterogeneous acidic catalysts. They are benign, noncorrosive, water and air stable, easily separated, and reusable [36]. However, the addition of a co-catalyst to such systems improve olefin conversion has not been reported.

In this work, we report a new and efficient olefin oligomerization reaction using $\mathrm{SO}_{3} \mathrm{H}$-functionalized ionic liquids (Scheme 1) and a co-catalyst (tricaprylylmethylammonium chloride) as substitutes for conventional acidic catalysts. It is noted that the co-catalyst can enhance the conversion of olefins. The effect of various parameters, such as different ionic liquids, ionic liquid loading, different co-catalysts, catalyst ratio (mole ratio of ionic liquid to co-catalyst), reaction time, pressure, temperature, different solvents, and source of reactants on the catalytic reaction was investigated and these parameters were optimized in a batch reactor. High yield and good selectivity were obtained via the use of the new catalyst system $\left(\mathrm{SO}_{3} \mathrm{H}\right.$-functionalized ionic liquids and co-catalyst) and the reaction mechanism was discussed on the basis of the experimental results. Furthermore, the recyclability of the catalyst system was examined.

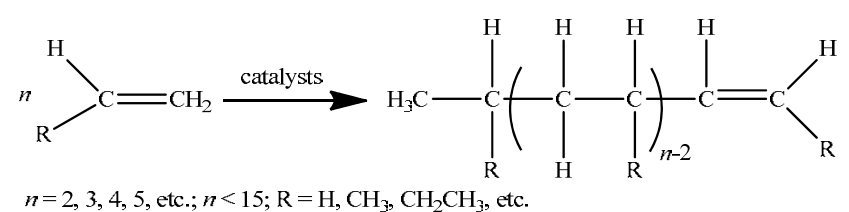

$n=2,3,4,5$, etc.; $n<15 ; \mathrm{R}=\mathrm{H}, \mathrm{CH}_{3}, \mathrm{CH}_{2} \mathrm{CH}_{3}$, etc

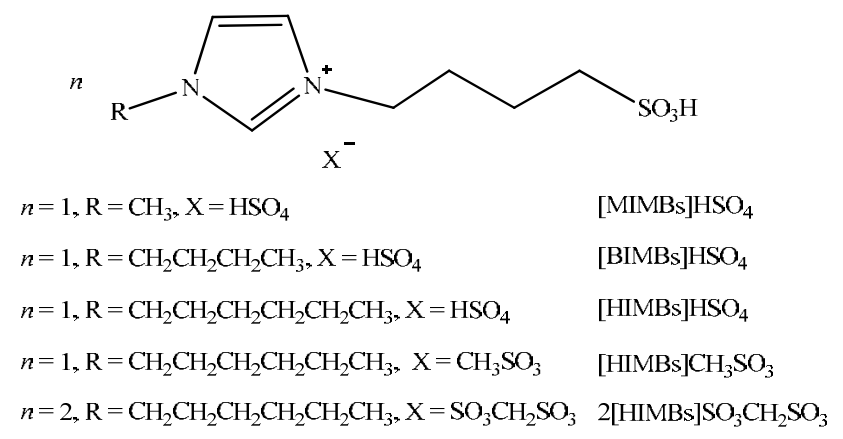

Scheme 1. The olefin oligomerization reaction and different Brönsted acidic ionic liquids used in this work.

\section{Experimental}

\subsection{General}

All the solvents and chemicals used were of analytical grade; they were used as received without further purification unless otherwise stated. N-methylimidazole and 1,4-butane sultone were purchased from Shanghai Chemicals Co., Ltd. 1-butylimidazole, 1-bromohexane, and tricaprylymethylammonium chloride were purchased from Energy Chemical. Ethylene (>99\%), propylene (>99\%), 1-butene (>99\%), and isobutene $(>99 \%)$ were purchased from Dalian Special Gases Co., Ltd.

The ${ }^{1} \mathrm{H}$ nuclear magnetic resonance (NMR) spectra and ${ }^{13} \mathrm{C}$ NMR spectra were obtained on an INOVA-400 MHz NMR spectrometer using tetramethylsilane (TMS) as the internal standard. Fourier transform infrared (FT-IR) spectra were recorded using $\mathrm{KBr}$ tablets on a NEXUS 870 spectrometer (Nicolet Instruments Co., USA). The absorbance spectra of 4-nitroaniline-based compounds were obtained on a PerkinElmer Lambda 35 UV/VIS spectrometer.

\subsection{Preparation of ILs}

$\mathrm{SO}_{3} \mathrm{H}$-functionalized ionic liquids were prepared according to previously reported procedures [37,38]. 1-butylmidazole and 1-hexylimidazole were synthesized from imidazole and halogenated hydrocarbon, respectively, as reported elsewhere $[39,40]$.

\subsubsection{Preparation of 1-alkyl-3-(butyl-4-sulfonate) imidazolium} betaines [37]

Stoichiometric amounts of 1,4-butane sultone and $\mathrm{N}$-alkylimidazole were stirred in toluene at $60^{\circ} \mathrm{C}$ for $24 \mathrm{~h}$. The generated solid zwitterion was washed three times with toluene to remove unreacted materials and dried under high vacuum at $70^{\circ} \mathrm{C}$ for $12 \mathrm{~h}$. Subsequently, the product was recrystallized to obtain a purer form.

\subsubsection{Preparation of $\mathrm{SO}_{3} \mathrm{H}$-functionalized ILs [38]}

A stoichiometric amount of sulfuric acid (98\%), methanesulfonic acid, or methanedisulfonic acid was added dropwise into the synthesized 1-alkyl-3-(butyl-4-sulfonate) imidazolium and stirred at $80{ }^{\circ} \mathrm{C}$ for $24 \mathrm{~h}$. The IL obtained was then washed three times with toluene and dried in a vacuum oven at $70{ }^{\circ} \mathrm{C}$ for $12 \mathrm{~h}$. The high-purity product obtained was quantified and assessed by NMR spectroscopy.

NMR spectral data in $\mathrm{D}_{2} \mathrm{O}$ and FT-IR spectral data corresponding to the ILs synthesized in this work are as follows. Chemical shifts are reported in parts per million (ppm, $\delta$ ) and referenced to $\mathrm{D}_{2} \mathrm{O}(\delta=4.73)$.

[MIMBs]HSO $4 .{ }^{1} \mathrm{H}$ NMR $\left(400 \mathrm{MHz}, \mathrm{D}_{2} \mathrm{O}\right): \delta 8.55(\mathrm{dd}, J=27.7$, $6.8 \mathrm{~Hz}, 1 \mathrm{H}), 7.33(\mathrm{~m}, 2 \mathrm{H}), 4.00(\mathrm{~m}, 2 \mathrm{H}), 3.68(\mathrm{~m}, 3 \mathrm{H}), 2.73(\mathrm{dd}, J$ $=15.2,8.1 \mathrm{~Hz}, 2 \mathrm{H}), 1.78(\mathrm{~m}, 2 \mathrm{H}), 1.54(\mathrm{~m}, 2 \mathrm{H}) .{ }^{13} \mathrm{C}$ NMR $(101$ $\mathrm{MHz}, \mathrm{D}_{2} \mathrm{O}$ ): $\delta 135.90(\mathrm{~s}), 123.66(\mathrm{~s}), 122.16$ (s), 50.08 (s), 48.90 (s), 35.67 (s), 28.07 (s), 20.92 (s). IR (KBr, v/cm-1): 3157 (C-H stretching vibration, MIM), 2960 (C-H stretching vibration, $\mathrm{CH}_{2}$ ), 1716 (C=C stretching vibration, MIM), 1574 (C=N 
stretching vibration, MIM), 1460 (C-H bending vibration, $\mathrm{CH}_{2}$ ), $1220\left(\mathrm{SO}_{2}\right.$ stretching vibration, $\left.-\mathrm{SO}_{3} \mathrm{H}\right), 1170,1039(\mathrm{~S}=0$ stretching vibration, $\left.-\mathrm{SO}_{3} \mathrm{H}\right), 759$ (C-C rocking vibration, $\left.\left(\mathrm{CH}_{2}\right)_{n}, n \geq 4\right), 580\left(-\mathrm{SO}_{3} \mathrm{H}\right.$, absorption peak).

[BIMBs] $\mathrm{HSO}_{4} .{ }^{1} \mathrm{H}$ NMR (400 MHz, $\left.\mathrm{D}_{2} \mathrm{O}\right): \delta 8.70(\mathrm{~d}, J=27.3$ $\mathrm{Hz}, 1 \mathrm{H}), 7.36(\mathrm{~s}, 2 \mathrm{H}), 4.07(\mathrm{dd}, J=14.6,5.1 \mathrm{~Hz}, 4 \mathrm{H}), 2.78(\mathrm{~m}$, $2 \mathrm{H}), 1.81(\mathrm{~d}, J=49.1 \mathrm{~Hz}, 2 \mathrm{H}), 1.67(\mathrm{~d}, J=23.5 \mathrm{~Hz}, 2 \mathrm{H}), 1.59$ (d, $J$ $=2.6 \mathrm{~Hz}, 2 \mathrm{H}), 1.16(\mathrm{~d}, J=2.1 \mathrm{~Hz}, 2 \mathrm{H}), 0.77(\mathrm{~m}, 3 \mathrm{H}) .{ }^{13} \mathrm{C}$ NMR (101 MHz, D 20$): \delta 135.20(\mathrm{~s}), 122.41$ (d, $J=21.6 \mathrm{~Hz}$ ), 121.74 (m), 50.07 (s), 49.17 (d, J = $40.4 \mathrm{~Hz}), 48.60$ (m), 31.18 (s), 28.09 (s), 20.96 (s), 18.75 (s), 12.61 (s). IR (KBr, v/cm-1): 3148 (C-H, MIM), 2965 (C-H, CH 2$), 1714$ (C=C, MIM), 1565 (C=N, MIM), $1466\left(\mathrm{C}-\mathrm{H}, \mathrm{CH}_{2}\right), 1223\left(\mathrm{SO}_{2},-\mathrm{SO}_{3} \mathrm{H}\right), 1167,1036\left(\mathrm{~S}=\mathrm{O},-\mathrm{SO}_{3} \mathrm{H}\right)$, 751 (C-C rocking vibration, $\left.\left(\mathrm{CH}_{2}\right)_{n}, n \geq 4\right), 578\left(-\mathrm{SO}_{3} \mathrm{H}\right)$.

[HIMBs] $\mathrm{HSO}_{4} .{ }^{1} \mathrm{H}$ NMR (400 MHz, $\left.\mathrm{D}_{2} \mathrm{O}\right): \delta 8.69(\mathrm{~m}, 1 \mathrm{H}), 7.41$ $(\mathrm{m}, 2 \mathrm{H}), 4.10(\mathrm{dt}, J=22.3,7.0 \mathrm{~Hz}, 4 \mathrm{H}), 2.78(\mathrm{dd}, J=38.1,30.4 \mathrm{~Hz}$, $2 \mathrm{H}), 1.89(\mathrm{~m}, 2 \mathrm{H}), 1.75(\mathrm{~m}, 2 \mathrm{H}), 1.60(\mathrm{~m}, 2 \mathrm{H}), 1.17(\mathrm{~s}, 6 \mathrm{H}), 0.74$ (d, $J=6.7 \mathrm{~Hz}, 3 \mathrm{H}) .{ }^{13} \mathrm{C}$ NMR (101 MHz, $\left.\mathrm{D}_{2} \mathrm{O}\right): \delta 135.16(\mathrm{~s})$, 122.35 (d, $J=19.7 \mathrm{~Hz}), 49.99$ (s), 49.59 (s), 48.91 (s), 30.22 (s), 29.00 (s), 28.06 (s), 24.90 (s), 21.68 (s), 20.89 (s), 13.14 (s). IR (KBr, v/cm-1): 3150 (C-H, MIM), 2933 (C-H, CH2), 1652 (C=C, MIM), 1565 (C=N, MIM), 1465 (C-H, CH $), 1185,1040$ (S=0, $\left.-\mathrm{SO}_{3} \mathrm{H}\right), 731$ (C-C rocking vibration, $\left.\left(\mathrm{CH}_{2}\right)_{n}, n \geq 4\right), 570$ $\left(-\mathrm{SO}_{3} \mathrm{H}\right)$.

[HIMBs] $\mathrm{CH}_{3} \mathrm{SO}_{3} .{ }^{1} \mathrm{H}$ NMR (400 MHz, $\left.\mathrm{D}_{2} \mathrm{O}\right): \delta 8.68(\mathrm{~m}, 1 \mathrm{H})$, $7.41(\mathrm{~m}, 2 \mathrm{H}), 4.10(\mathrm{dt}, J=22.2,7.0 \mathrm{~Hz}, 4 \mathrm{H}), 2.82(\mathrm{dd}, J=14.2,6.6$ $\mathrm{Hz}, 2 \mathrm{H}), 2.68(\mathrm{~s}, 3 \mathrm{H}), 1.90(\mathrm{~m}, 2 \mathrm{H}), 1.74(\mathrm{~m}, 2 \mathrm{H}), 1.61$ (dt, $J=$ 18.3, $7.7 \mathrm{~Hz}, 2 \mathrm{H}), 1.16(\mathrm{~s}, 6 \mathrm{H}), 0.72(\mathrm{~d}, J=6.8 \mathrm{~Hz}, 3 \mathrm{H}) .{ }^{13} \mathrm{C}$ NMR (101 MHz, $\mathrm{D}_{2} \mathrm{O}$ ): $\delta 135.15$ (s), 122.36 (d, $J=19.7 \mathrm{~Hz}$ ), 50.00 (s), 49.59 (s), 48.92 (s), 38.40 (s), 30.22 (s), 29.01 (s), 28.08 (s), 24.91 (s), 21.68 (s), 20.90 (s), 13.15 (s). IR (KBr, v/cm-1): 3145 (C-H, MIM), 2934 (C-H, CH 2$), 1655$ (C=C, MIM), 1565 (C=N, MIM), 1460 (C-H, CH2), 1193, 1040 (S=O, -SO3H), 778 (C-C rocking vibration, $\left.\left(\mathrm{CH}_{2}\right)_{n}, n \geq 4\right), 572\left(-\mathrm{SO}_{3} \mathrm{H}\right)$.

2[HIMBs] $\mathrm{SO}_{3} \mathrm{CH}_{2} \mathrm{SO}_{3} .{ }^{1} \mathrm{H}$ NMR (400 MHz, $\left.\mathrm{D}_{2} \mathrm{O}\right): \delta 8.68(\mathrm{~m}$, 1H), $7.41(\mathrm{~m}, 2 \mathrm{H}), 4.17(\mathrm{~d}, J=13.1 \mathrm{~Hz}, 1 \mathrm{H}), 4.08(\mathrm{~m}, 4 \mathrm{H}), 2.75$ (m, 2H), $1.90(\mathrm{~m}, 2 \mathrm{H}), 1.74(\mathrm{~m}, 2 \mathrm{H}), 1.59(\mathrm{~m}, 2 \mathrm{H}), 1.16(\mathrm{~s}, 6 \mathrm{H})$, 0.72 (d, $J=6.8 \mathrm{~Hz}, 3 \mathrm{H}) .{ }^{13} \mathrm{C}$ NMR (101 MHz, $\left.\mathrm{D}_{2} \mathrm{O}\right): \delta 135.16(\mathrm{~s})$, 122.36 (d, $J=19.8 \mathrm{~Hz}), 66.33$ (s), 50.01 (s), 49.59 (s), 48.92 (s), 30.22 (s), 29.01 (s), 28.08 (s), 24.91 (s), 21.68 (s), 20.91 (s), 13.15 (s).IR (KBr, $v / \mathrm{cm}^{-1}$ ): 3140 (C-H, MIM), $2934\left(\mathrm{C}-\mathrm{H}, \mathrm{CH}_{2}\right)$, 1728 (C=C, MIM), 1565 (C=N, MIM), 1466 (C-H, CH2), 1220 $\left(\mathrm{SO}_{2},-\mathrm{SO}_{3} \mathrm{H}\right) 1164,1015\left(\mathrm{~S}=0,-\mathrm{SO}_{3} \mathrm{H}\right), 795$ (C-C rocking vibration, $\left.\left(\mathrm{CH}_{2}\right)_{n}, n \geq 4\right), 575\left(-\mathrm{SO}_{3} \mathrm{H}\right)$.

\subsection{Catalytic experiments}

All the reactions were conducted in a $100-\mathrm{mL}$ autoclave with polytetrafluoroethylene tubing inside and magnetic stirring. In a typical reaction, $0.01 \mathrm{~mol}$ ionic liquid, $0.08 \mathrm{~mol}$ olefin, and $6 \mathrm{~mL}$ of cyclohexane were successively added and allowed to react at $120^{\circ} \mathrm{C} /$ self-pressure for $6 \mathrm{~h}$. After the reaction, the autoclave was cooled to $-20^{\circ} \mathrm{C}$ over $1 \mathrm{~h}$ and the ionic liquid was separated from the upper organic phase by layering. The upper organic products were qualitatively and quantitatively analyzed by gas chromatography/mass spectrometry (GC/MS) (Agilent 7890A/5975C) and GC (Agilent 6820 equipped with a flame ionization detector (FID), respectively. The ionic liquid could be reused in the next run without any additional treatment. The concentrations of the reactant and products were calculated from the areas of the corresponding chromatograph peaks.

According to previous studies [41,42], taking isobutene as an example, the conversion $(X)$ of light olefins and selectivity $(S)$ of products can be calculated using the following equations:

$$
\begin{gathered}
X_{\text {isobutene }}=\left(2 c_{\text {dimers }}+3 c_{\text {trimers }}+4 c_{\text {tetramers }}\right) /\left(c_{\text {isobutene out }}+\right. \\
\left.2 c_{\text {dimers }}+3 c_{\text {trimers }}+4 c_{\text {tetramers }}\right) \times 100 \% \\
S_{\text {dimers }}=c_{\text {dimers }} / \sum c_{\text {oligomers }} \times 100 \% \\
S_{\text {trimers }}=c_{\text {trimers }} / \sum c_{\text {oligomers }} \times 100 \% \\
S_{\text {tetramers }}=c_{\text {tetramers }} / \sum c_{\text {oligomers }} \times 100 \%
\end{gathered}
$$

\section{Results and discussion}

\subsection{Acidity analysis of $\mathrm{SO}_{3} \mathrm{H}$-functionalized ionic liquids}

To compare the acidity of synthetic ionic liquids, the acid strengths of $\mathrm{SO}_{3} \mathrm{H}$-functionalized ionic liquids were examined by a PerkinElmer Lambda 35 UV/VIS spectrometer according to previously reported methods $[43,44]$. For comparison purposes, the acidities of the ionic liquids were determined using 4-nitroaniline ( $\mathrm{pKa}$ value of 0.99 ) as the indicator in ethanol and the Hammett function $\left(H_{0}\right)$ could be calculated using the following equation Eq. (1).

$$
H_{0}=\mathrm{p} K(\mathrm{~A}) \mathrm{aq}+\log \left([\mathrm{A}] \mathrm{s} /\left[\mathrm{AH}^{+}\right] \mathrm{s}\right)
$$

At the same 4-nitroaniline concentration $(5.0 \mathrm{mg} / \mathrm{L})$ and IL concentration $(10 \mathrm{mmol} / \mathrm{L})$ in ethanol, we examined the $H_{0}$ values. The blank solution of 4-nitroaniline in ethanol exhibited maximum absorption at $370 \mathrm{~nm}$. When an IL was added, the maximum absorption of 4-nitroaniline decreased. Fig. 1(a) shows the absorbance of the unprotonated form of 4-nitroaniline in different - $\mathrm{R}$ group ILs. The trend is as follows: $[\mathrm{HIMBs}] \mathrm{HSO}_{4}>\left[\mathrm{BIMBs} \mathrm{HSO}_{4}>[\mathrm{MIMBs}] \mathrm{HSO}_{4}\right.$. The $\mathrm{H}_{0}$ values of the three ILs were calculated (Table 1) and it could be found that their acidities were in the following order: [HIMBs] $\mathrm{HSO}_{4}$

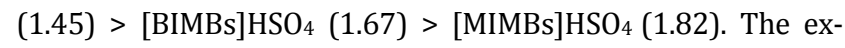
perimental results indicate that ILs with longer $-\mathrm{R}$ groups may have greater acidity. Fig. 1(b) shows the absorbance of 4-nitroaniline in different anionic ILs. The order of absorbance is as follows: 2[HIMBs] $\mathrm{SO}_{3} \mathrm{CH}_{2} \mathrm{SO}_{3}>$ [HIMBs] $\mathrm{HSO}_{4}>$ [HIMBs] $\mathrm{CH}_{3} \mathrm{SO}_{3}$. From Table 1 , it could be inferred that the acidities of these three ILs were in the following order: $2[\mathrm{HIMBs}] \mathrm{SO}_{3} \mathrm{CH}_{2} \mathrm{SO}_{3}$ (0.14) > $[\mathrm{HIMBs}] \mathrm{HSO}_{4}$ (1.45) > [HIMBs] $\mathrm{CH}_{3} \mathrm{SO}_{3}$ (1.53). It is obvious that ILs with different anions have different acidity values. Besides, it is noteworthy that the acidity of 2 [HIMBs] $\mathrm{SO}_{3} \mathrm{CH}_{2} \mathrm{SO}_{3}$ is very high, which may influence the reaction activity.

\subsection{Effect of different ionic liquids on the reaction}

Probe tests on olefin oligomerization reactions catalyzed by different ILs (IL/isobutene $=10 \%$ molar ratio) were carried out at $120{ }^{\circ} \mathrm{C} /$ self-pressure for $6 \mathrm{~h}$; the results are illustrated in Table 2. It is well known that the catalytic activities of ILs are greatly affected by their structures. When using [HIMBs] $\mathrm{HSO}_{4}$ 

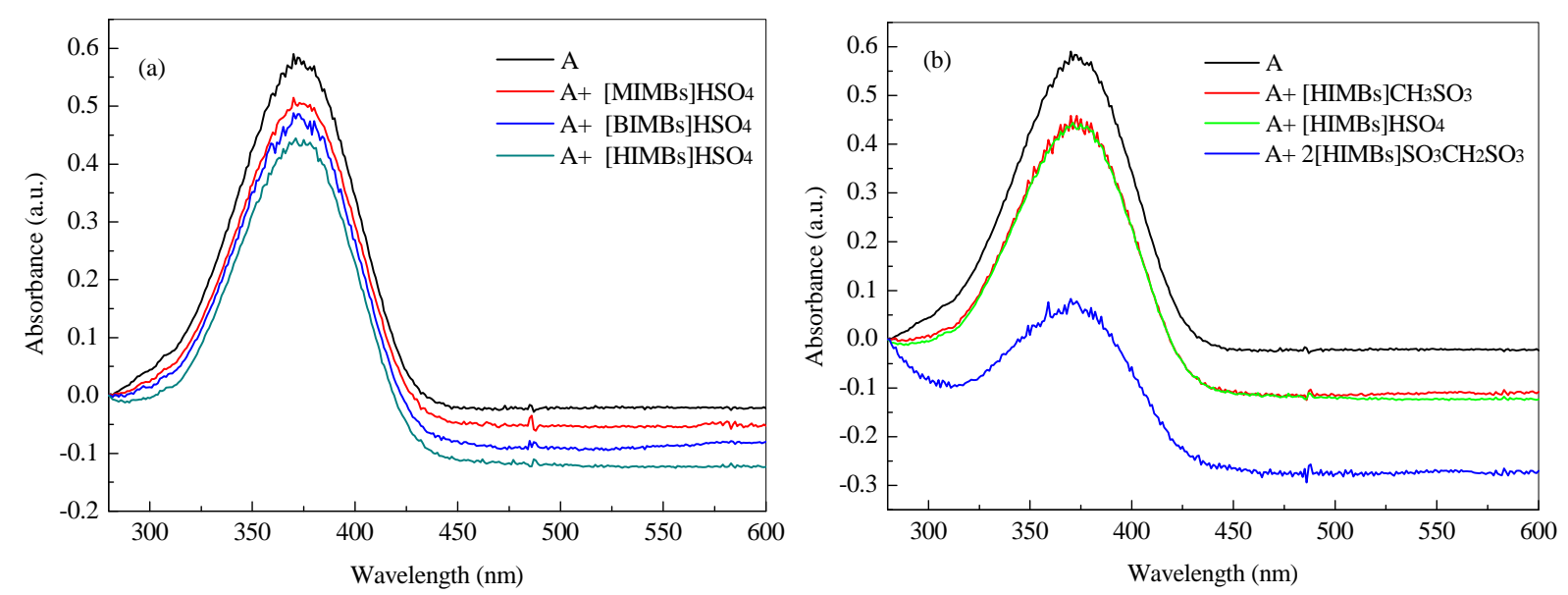

Fig. 1. Absorption spectra of 4-nitroaniline (A) with different $\mathrm{SO}_{3} \mathrm{H}$-functionalized ILs in ethanol. (a) Absorption spectra of different -R group ILs; (b) Absorption spectra of different anionic ILs.

Table 1

$\mathrm{H}_{0}$ values of different $\mathrm{SO}_{3} \mathrm{H}$-functionalized ILs in ethanol.

\begin{tabular}{lccc}
\hline lonic liquid & {$[\mathrm{A}](\%)$} & {$[\mathrm{AH}+(\%)$} & $H_{0}$ \\
\hline $\mathrm{A}^{*}$ & 100 & 0 & - \\
{$[\mathrm{MIMBs}] \mathrm{HSO}_{4}$} & 87.1 & 12.9 & 1.82 \\
{$[\mathrm{BIMBs}] \mathrm{HSO}_{4}$} & 82.7 & 17.3 & 1.67 \\
{$[\mathrm{HIMBs}] \mathrm{HSO}_{4}$} & 74.2 & 25.8 & 1.45 \\
{$\left[\mathrm{HIMBs}_{3} \mathrm{CH}_{3} \mathrm{SO}_{3}\right.$} & 77.6 & 22.4 & 1.53 \\
$2[\mathrm{HIMBs}] \mathrm{SO}_{3} \mathrm{CH}_{2} \mathrm{SO}_{3}$ & 14.0 & 86.0 & 0.14 \\
\hline
\end{tabular}

*4-nitroaniline.

as the catalyst (Table 2, entry 3), the conversion of isobutene was better than that obtained using other ionic liquids (Table 2, entries 1 and 2), which indicates that the length of the side chain on the cation had an impact on the catalytic performance. The catalytic activity order of different - $\mathrm{R}$ group ionic liquids was found to be $[\mathrm{HIMBs}] \mathrm{HSO}_{4}>[\mathrm{BIMBs}] \mathrm{HSO}_{4}>[\mathrm{MIMBs}] \mathrm{HSO}_{4}$, consistent with the $H_{0}$ values examined in Table 1 . These results showed that the acidity of an IL plays a significant role in determining its catalytic activity for olefin oligomerization. Besides, ILs with long -R groups exhibit good lipophilicity, which can promote the olefin oligomerization reaction.

Furthermore, we studied the effect of ILs with different anions on the olefin oligomerization reaction. As shown in Table 2 , the catalytic activity order of ILs with different anions is [HIMBs] $\mathrm{HSO}_{4}>2$ [HIMBs] $\mathrm{SO}_{3} \mathrm{CH}_{2} \mathrm{SO}_{3}>[\mathrm{HIMBs}] \mathrm{CH}_{3} \mathrm{SO}_{3}$, which is not consistent with the sequence of acidity examined in Table 1. The results may be ascribed to the strong acidity of 2 [HIMBs] $\mathrm{SO}_{3} \mathrm{CH}_{2} \mathrm{SO}_{3}$, which may influence the reaction activity observed in this study. Besides, the catalytic activity of [HIMBs] $\mathrm{HSO}_{4}$ is better than that activity of [HIMBs] $\mathrm{CH}_{3} \mathrm{SO}_{3}$, which is consistent with the sequence of acidity. From the experimental results shown in Table 2, we chose [HIMBs] $\mathrm{HSO}_{4}$ as the catalyst for further experimentation in this study.

\subsection{Optimization of reaction conditions}

To optimize the reaction conditions of olefin oligomerization, ionic liquid loading, different co-catalysts, catalyst ratio (mole ratio of ionic liquid to co-catalyst), reaction time, pressure, temperature, solvents, source of reactants, and reusability of the catalyst system were investigated using [HIMBs] $\mathrm{HSO}_{4}$ as the catalyst.

\subsubsection{Effect of ionic liquid loading ([HIMBs]HSO $\mathrm{H}_{4}$ /isobutene molar ratio)}

It can be seen from Table 3 that the selectivity of trimers reached a maximum (24.60\%) and then decreased as the [HIMBs] $\mathrm{HSO}_{4} /$ isobutene molar ratio increased. Meanwhile, the selectivity of dimers reduced rapidly, while the selectivity of tetramers increased little when the [HIMBs] $\mathrm{HSO}_{4} /$ isobutene molar ratio increased. The product distribution may be attributed to the increase in the acidity of the reaction system. There are no isomers of isobutene in the products. It is surprising that the conversion of isobutene initially increased and then decreased slowly with an increase in the IL loading. In the olefin oligomerization reaction, ionic liquids with moderate

Table 2

Olefin oligomerization in different ionic liquids.

\begin{tabular}{lcccccc}
\hline \multirow{2}{*}{ Entry } & \multirow{2}{*}{$\mathrm{ILs}$} & $X_{\text {isobutene }}(\%)$ & \multicolumn{3}{c}{$S_{\text {oligomers }}(\%)$} \\
\cline { 3 - 7 } & & 7.68 & Dimers & Trimers & Tetramers & Isomers \\
\hline 1 & {$[\mathrm{MIMBs}] \mathrm{HSO}_{4}$} & 8.90 & 82.42 & 8.92 & 0.00 & 0 \\
2 & {$[\mathrm{BIMBs}] \mathrm{HSO}_{4}$} & 23.50 & 86.84 & 7.16 & 0.00 & 0 \\
3 & {$[\mathrm{HIMBs}] \mathrm{HSO}_{4}$} & 3.35 & 88.74 & 7.51 & 0.76 & 0 \\
4 & {$[\mathrm{HIMBs}] \mathrm{CH}_{3} \mathrm{SO}_{3}$} & 8.89 & 85.65 & 0.70 & 0.00 & 0 \\
5 & $2[\mathrm{HIMBs}] \mathrm{SO}_{3} \mathrm{CH}_{2} \mathrm{SO}_{3}$ & 64.26 & 11.88 & 0.00 & 0 \\
\hline
\end{tabular}

Reaction conditions: IL/isobutene $=10 \%$ molar ratio, temperature $120^{\circ} \mathrm{C}$, time $6 \mathrm{~h}$, initial reaction pressure $0 \mathrm{MPa}$ (self-pressure), cyclohexane solvent, no co-catalyst. 
Table 3

Effect of ionic liquid loading ([HIMBs] $\mathrm{HSO}_{4}$ /isobutene molar ratio) on olefin oligomerization.

\begin{tabular}{|c|c|c|c|c|c|}
\hline \multirow{2}{*}{$\begin{array}{l}\text { [HIMBs] } \mathrm{HSO}_{4} / \text { isobutene } \\
\text { molar ratio }(\%)\end{array}$} & \multirow{2}{*}{$X_{\text {isobutene }}(\%)$} & \multicolumn{4}{|c|}{$S_{\text {oligomers }}(\%)$} \\
\hline & & Dimers & Trimers & Tetramers & Isomers \\
\hline 5 & 7.78 & 92.10 & 2.41 & 0.00 & 0 \\
\hline 10 & 23.50 & 90.74 & 7.51 & 0.76 & 0 \\
\hline 15 & 30.27 & 82.24 & 10.09 & 0.77 & 0 \\
\hline 20 & 25.52 & 67.18 & 16.92 & 1.33 & 0 \\
\hline 25 & 20.20 & 55.28 & 24.60 & 1.00 & 0 \\
\hline 30 & 18.49 & 52.87 & 22.88 & 3.64 & 0 \\
\hline
\end{tabular}

Reaction conditions: $80 \mathrm{mmol}$ isobutene, $120^{\circ} \mathrm{C}, 6 \mathrm{~h}$, initial reaction pressure $0 \mathrm{MPa}$ (self-pressure), cyclohexane solvent, no co-catalyst.

acidity show high catalytic performance. Large amounts of an ionic liquid with strong acidity may lower the reaction activity under the given conditions. In this work, the best selectivity for trimers was obtained when the [HIMBs] $\mathrm{HSO}_{4} /$ isobutene molar ratio was $25 \%$. We took some measures such as adding the co-catalyst and adjusting the reaction temperature and pressure to improve the conversion of isobutene in the subsequent experiments.

\subsubsection{Effect of different co-catalysts on the reaction}

In order to obtain a high conversion of isobutene, we added some co-catalysts, which acted as surfactants, to promote olefin oligomerization. As can be seen from Table 4, different co-catalysts have different effects on the conversion of isobutene. The conversion of isobutene increased when a co-catalyst was added to the reaction system. Among the three different co-catalysts, under the given conditions, tricaprylylmethylammonium chloride greatly improved the conversion of isobutene, while the other co-catalysts (dimethyldioctadecylammonium chloride and dimethyldioctadecylammonium bromide) only slightly improved the conversion of isobutene.
Considering the experimental results, we chose tricaprylylmethylammonium chloride as the optimal co-catalyst to improve the conversion of olefins.

\subsubsection{Effect of co-catalyst loading (molar ratio of [HIMBs]HSO${ }_{4}$ to tricaprylylmethylammonium chloride)}

Based on the above analysis, tricaprylylmethylammonium chloride was chosen as the optimal co-catalyst. As shown in Table 5, when the [HIMBs] $\mathrm{HSO}_{4} /$ tricaprylylmethylammonium chloride molar ratio increased, the conversion of isobutene increased initially and then decreased. Further, when the [HIMBs] $\mathrm{HSO}_{4} /$ co-catalyst molar ratio was 20:1, the conversion of isobutene was maximum (36.68\%); additionally, good selectivity of dimers $(76.59 \%)$, trimers $(15.25 \%)$, and tetramers $(1.23 \%)$ could be achieved. Therefore, the optimal molar ratio of [HIMBs] $\mathrm{HSO}_{4}$ to co-catalyst was chosen to be 20:1.

\subsubsection{Effect of reaction temperature}

Reaction temperature is an important parameter affecting the reaction activity of the olefin oligomerization reaction. In this work, the effect of reaction temperature was studied in the

Table 4

Effect of different co-catalysts on the olefin oligomerization reaction.

\begin{tabular}{|c|c|c|c|c|c|}
\hline \multirow{2}{*}{ Co-catalyst } & \multirow{2}{*}{$X_{\text {isobutene }}(\%)$} & \multicolumn{4}{|c|}{$S_{\text {oligomers }}(\%)$} \\
\hline & & Dimers & Trimers & Tetramers & Isomers \\
\hline Tricaprylylmethylammonium chloride (liquid) & 26.10 & 42.56 & 3.26 & 0 & 0 \\
\hline Dimethyldioctadecylammonium chloride (solid) & 20.36 & 65.25 & 1.46 & 0 & 0 \\
\hline Dimethyldioctadecylammonium bromide (solid) & 20.80 & 72.38 & 1.02 & 0 & 0 \\
\hline No co-catalyst & 20.20 & 55.28 & 24.60 & 1 & 0 \\
\hline
\end{tabular}

Reaction conditions: [HIMBs] $\mathrm{HSO}_{4} /$ isobutene $=25 \%$ molar ratio, [HIMBs] $\mathrm{HSO}_{4}$ :Co-catalyst $=10: 1$ molar ratio, $120{ }^{\circ} \mathrm{C}, 6 \mathrm{~h}$, initial reaction pressure 0 MPa (self-pressure), cyclohexane solvent.

Table 5

Effect of co-catalyst (tricaprylylmethylammonium chloride) loading on the olefin oligomerization reaction (molar ratio of [HIMBs] $\mathrm{HSO}{ }_{4}$ to co-catalyst).

\begin{tabular}{|c|c|c|c|c|c|}
\hline \multirow{2}{*}{$\begin{array}{l}\text { [HIMBs] } \mathrm{HSO}_{4} / \text { co-catalyst } \\
\text { molar ratio }\end{array}$} & \multirow{2}{*}{$X_{\text {isobutene }}(\%)$} & \multicolumn{4}{|c|}{$S_{\text {oligomers }}(\%)$} \\
\hline & & Dimers & Trimers & Tetramers & Isomers \\
\hline$\overline{1: 1}$ & 1.16 & 4.96 & 0.85 & 0.00 & 0 \\
\hline $10: 1$ & 26.10 & 42.56 & 3.26 & 0.00 & 0 \\
\hline $20: 1$ & 36.68 & 76.59 & 15.25 & 1.23 & 0 \\
\hline $30: 1$ & 25.38 & 69.32 & 19.94 & 1.56 & 0 \\
\hline $40: 1$ & 17.79 & 71.40 & 14.26 & 0.00 & 0 \\
\hline No co-catalyst & 20.20 & 55.28 & 24.60 & 1.00 & 0 \\
\hline
\end{tabular}

Reaction conditions: [HIMBs] $\mathrm{HSO}_{4} /$ isobutene $=25 \%$ molar ratio, $120{ }^{\circ} \mathrm{C}, 6 \mathrm{~h}$, initial reaction pressure $0 \mathrm{MPa}$ (self-pressure), cyclohexane solvent, tricaprylylmethylammonium chloride as co-catalyst. 


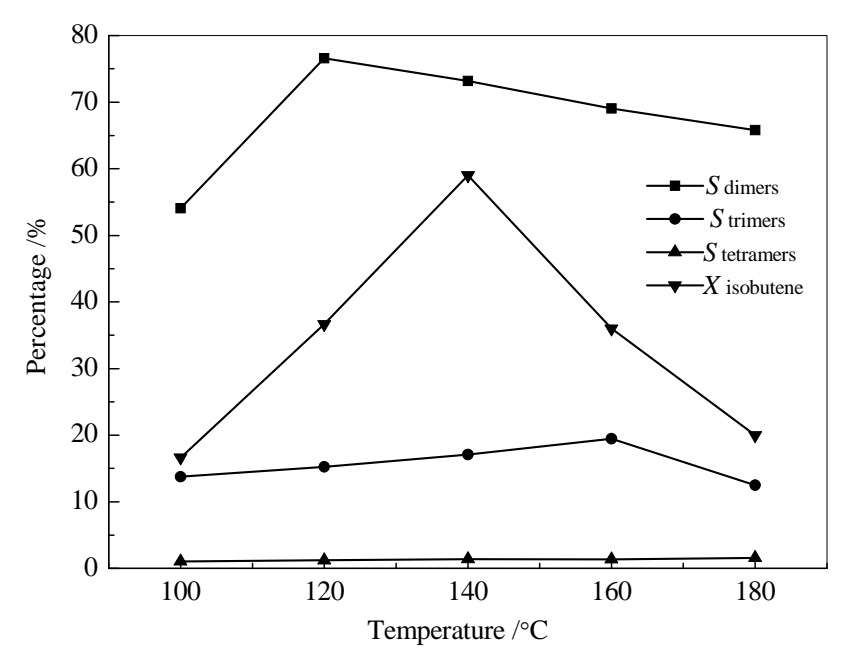

Fig. 2. Effect of reaction temperature on the olefin oligomerization reaction. Reaction conditions: [HIMBs] $\mathrm{HSO}_{4} /$ isobutene $=25 \%$ molar ratio, $[\mathrm{HIMBs}] \mathrm{HSO}_{4}:$ Co-catalyst $=20: 1$ molar ratio, $6 \mathrm{~h}$, initial reaction pressure $0 \mathrm{MPa}$ (self-pressure), cyclohexane solvent, co-catalyst tricaprylylmethylammonium chloride.

range of 100 to $180{ }^{\circ} \mathrm{C}$. As can be seen from Fig. 2, the conversion of isobutene increased rapidly when the reaction temperature increased from 100 to $140{ }^{\circ} \mathrm{C}$. In contrast, at reaction temperatures above $140{ }^{\circ} \mathrm{C}$, the conversion of isobutene reduced rapidly. It can be observed that when the reaction temperature was $140{ }^{\circ} \mathrm{C}$, the conversion of isobutene was maximum (59.03\%). Besides, at this temperature, the selectivity values for dimers, trimers, and tetramers were $73.19 \%$, $17.07 \%$, and $1.40 \%$, respectively. From these results, it was inferred that the optimum reaction temperature was $140{ }^{\circ} \mathrm{C}$.

\subsubsection{Effect of reaction pressure}

Reaction pressure also exerts an effect on the activity of the olefin oligomerization reaction. In order to increase the initial reaction pressure, we filled $\mathrm{N}_{2}$ in the reactor at room temperature. It can be seen from Fig. 3 that when the initial pressure was $0 \mathrm{MPa}$ (self-pressure), the conversion of isobutene was $59.03 \%$ and the selectivity values of dimers, trimers and, tetramers were $73.19 \%, 17.07 \%$, and $1.40 \%$, respectively. With an increase in the initial pressure, the conversion of isobutene was promoted and could reach a value as high as $75.77 \%$ when the initial pressure was 1.0 MPa. The results of olefin oligomerization were more positive at lower pressures. When the oligomerization reaction was carried out at $140{ }^{\circ} \mathrm{C}$, low-boiling liquid products evaporated. With increasing pressure, it is possible to decrease the concentration of olefins in the gas phase, which could result in an enhancement in the reaction activity at lower pressures. However, with a further increase in the initial pressure to $2.0 \mathrm{MPa}$, the conversion of isobutene changed only a little. In addition, when the initial pressure was 3.0 MPa, the conversion of isobutene and selectivity of oligomers hardly changed when compared to values observed when the initial pressure was 2.0 MPa. The influence of olefin concentration may reduce in the liquid phase at high pressures, which may explain the obtained results. As shown in Fig. 3, the optimum

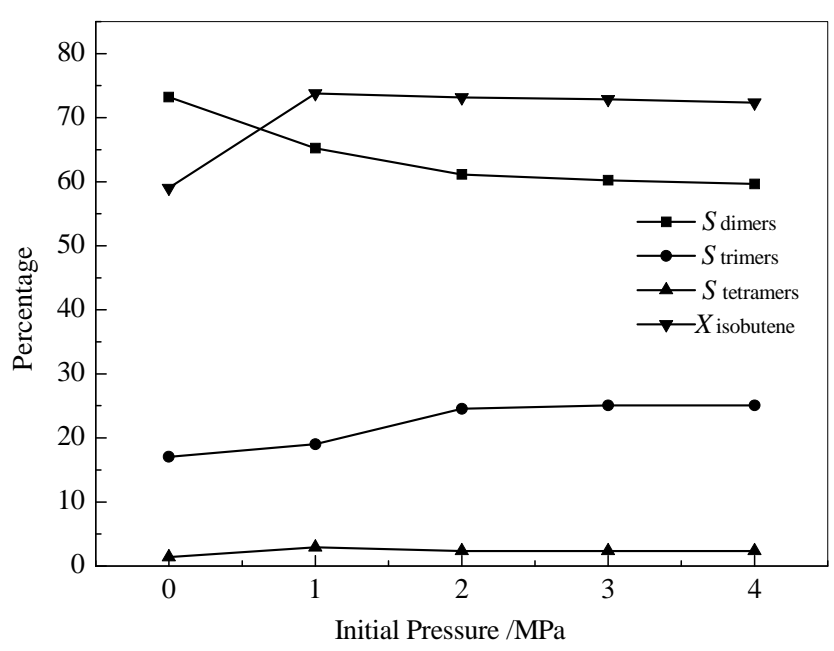

Fig. 3. Effect of reaction pressure on the reaction. Reaction conditions: [HIMBs]HSO ${ }_{4} /$ isobutene $=25 \%$ molar ratio, $[\mathrm{HIMBs}] \mathrm{HSO}_{4}$ : co-catalyst $=$ 20:1 molar ratio, $140^{\circ} \mathrm{C}, 6 \mathrm{~h}$, cyclohexane solvent, co-catalyst tricaprylylmethylammonium chloride.

initial reaction pressure was $2.0 \mathrm{MPa}$.

\subsubsection{Effect of reaction time}

The effect of reaction time on the olefin oligomerization was also studied in the reaction time period range of 2 to $10 \mathrm{~h}$. It can be seen in Fig. 4 that the conversion of isobutene increased significantly when the reaction time was $<8 \mathrm{~h}$, which indicates that prolonging the reaction time is conducive to the formation of oligomers. Furthermore, when the reaction time was $10 \mathrm{~h}$, the conversion of isobutene changed very little, which means that the reaction may have reached an equilibrium state. Hence, we chose $8 \mathrm{~h}$ as the optimum reaction time and achieved a high conversion of isobutene $(82.65 \%)$ and high selectivity of dimers (63.34\%), trimers (20.74\%), and tetramers (2.35\%).

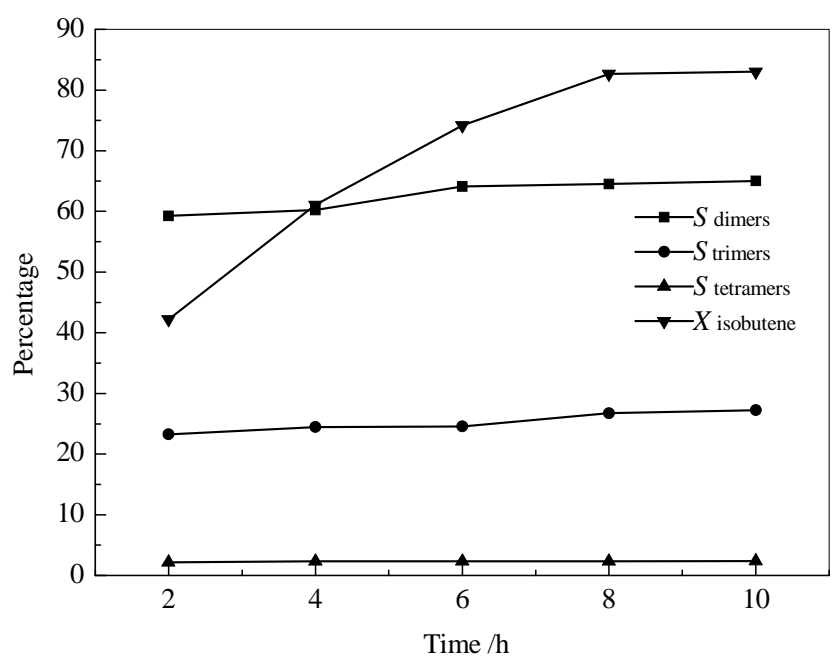

Fig. 4. Effect of reaction time on the olefin oligomerization reaction. Reaction conditions: [HIMBs] $\mathrm{HSO}_{4} /$ isobutene $=25 \%$ molar ratio, [HIMBs]HSO ${ }_{4}$ :co-catalyst $=20: 1$ molar ratio, $140{ }^{\circ} \mathrm{C}$, initial reaction pressure $2.0 \mathrm{MPa}$, cyclohexane solvent, co-catalyst tricaprylylmethylammonium chloride. 


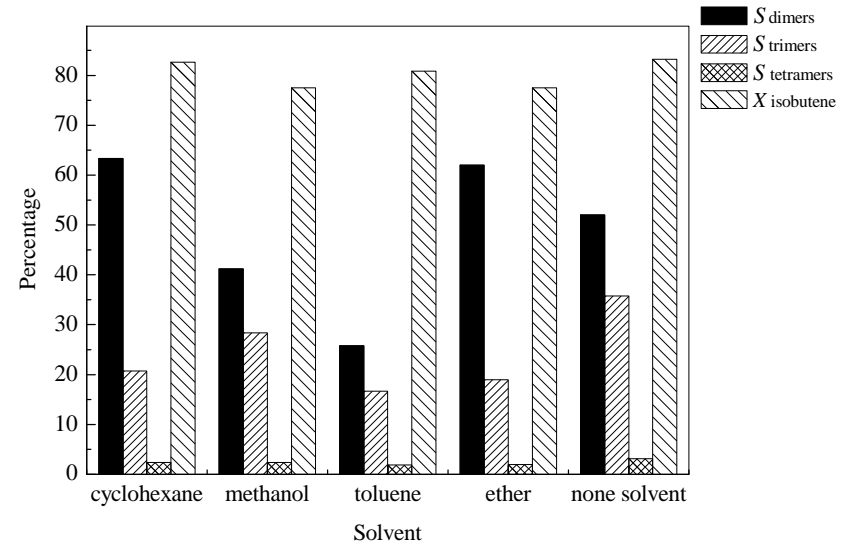

Fig. 5. Effect of different solvents on the olefin oligomerization reaction. Reaction conditions: [HIMBs] $\mathrm{HSO}_{4} /$ isobutene $=25 \%$ molar ratio, [HIMBs] $\mathrm{HSO}_{4}: \mathrm{co}$-catalyst $=20: 1$ molar ratio, $140{ }^{\circ} \mathrm{C}, 8 \mathrm{~h}$, initial reaction pressure $2.0 \mathrm{MPa}$, co-catalyst tricaprylylmethylammonium chloride.

\subsubsection{Effect of different solvents on the reaction}

The solvent used during the olefin oligomerization reaction has an effect on the conversion of isobutene and the selectivity of polymers. The results are shown in Fig. 5; when using cyclohexane as the solvent, the conversion of isobutene and selectivity values of dimers, trimers, and tetramers were found to be $82.65 \%, 63.34 \%, 20.74 \%$, and $2.35 \%$, respectively. It is noted that when there was no additional solvent, which means that [HIMBs] $\mathrm{HSO}_{4}$ plays the dual role of catalyst and solvent, the highest value of isobutene conversion was observed (83.21\%). Further, good selectivities of dimers $(52.02 \%)$, trimers (35.80\%), and tetramers (3.14\%) were observed. On the basis of the obtained experimental results, it was inferred that the optimal reaction conditions included no solvent.

In conclusion, the optimal conditions are as follows:

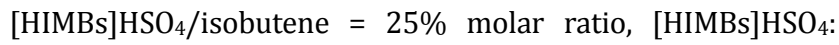
co-catalyst $=20: 1$ molar ratio, $140{ }^{\circ} \mathrm{C}, 8 \mathrm{~h}$, initial reaction pressure of $2.0 \mathrm{MPa}$, no additional solvent, and a catalyst system containing [HIMBs]HSO${ }_{4}$ and co-catalyst, (tricaprylylmethylammonium chloride).

\subsubsection{Oligomerization of various light olefins with the developed catalyst system}

Under the optimal conditions, four different light olefins were studied to examine their conversion and oligomer selectivity. As shown in Table 6, ethylene, propylene, and isobutene exhibit high conversion during the oligomerization reaction.
During the ethylene oligomerization reaction, very high conversion and selectivity could be achieved. The conversion of ethylene and selectivity values of dimers, trimers, tetramers, and hexamers were $59.01 \%, 15.96 \%, 38.96 \%, 28.36 \%$, and $1.16 \%$, respectively (Table 6 , entry 1 ). When the olefin was propylene, a high conversion (43.87\%) and high selectivity values of dimers $(67.01 \%)$, trimers $(9.44 \%)$, and tetramers $(1.35 \%)$ were observed (Table 6 , entry 2 ). The conversion of isobutene and selectivity of oligomers were described above. It is noteworthy that 1-butene was inclined to form isomers and the selectivity of isomers was $64.44 \%$. The conversion of 1-butene to polymers was only $4.66 \%$ (Table 6 , entry 3 ). On the basis of the experimental results, it can be concluded that the catalysts ([HIMBs] $\mathrm{HSO}_{4}$ and co-catalyst) were effective in catalyzing the olefin oligomerization reaction. The structures of the oligomers [45] are shown in Table 7 to examine the oligomerization of olefins.

\subsubsection{Reusability of the catalyst system}

In order to investigate the reusability of the catalyst system developed in this work, a series of recycling experiments was conducted. During the olefin oligomerization reaction, the catalyst system can be easily separated from the products by layering. Furthermore, the catalyst system could be reused in the next run without any additional treatment. It can be seen from Fig. 6 that after eight runs, the conversion of isobutene decreased from $78.66 \%$ to $67.43 \%$ and the selectivity of trimers decreased from $28.17 \%$ to $11.63 \%$. Additionally, the selectivity of dimers increased from $64.70 \%$ to $85.60 \%$. After eight runs, the recovery of the catalyst system was $86.16 \%$. Furthermore, the FT-IR spectra of fresh and reused catalyst systems were compared as shown in Fig. 7. There are no obvious differences in the FT-IR spectra of the two systems, which indicates that the structure of catalyst system hardly changed after eight runs. This observation confirms that the loss of the catalyst system may be the main reason for the decrease in catalytic activity, as observed in this work.

\subsection{Mechanism of the olefin oligomerization reaction}

Based on previous studies [10,46,47] and our experimental results, a feasible reaction mechanism for the olefin oligomerization reaction is postulated, as shown in Scheme 2. Isobutene was considered as the model olefin. According to the product distribution results, the first step is the protonation of isobutene to generate carbocations, which can react with the nucle-

Table 6

Oligomerization of various light olefins with the developed catalyst system.

\begin{tabular}{|c|c|c|c|c|c|c|c|}
\hline \multirow{2}{*}{ Entry } & \multirow{2}{*}{ Olefins } & \multirow{2}{*}{$X_{\text {olefin }}{ }^{\text {a }}(\%)$} & \multicolumn{5}{|c|}{$S_{\text {oligomers }}(\%)$} \\
\hline & & & Dimers & Trimers & Tetramers & Hexamers & Isomers \\
\hline 1 & Ethylene & 59.01 & 15.96 & 38.96 & 28.36 & 1.16 & 0 \\
\hline 2 & Propylene & 43.87 & 67.01 & 9.44 & 1.35 & 0 & 0 \\
\hline 3 & 1-butene & 4.66 & 31.57 & 3.99 & 0 & 0 & 64.44 \\
\hline 4 & Isobutene & 83.27 & 52.02 & 35.80 & 3.14 & 0 & 0 \\
\hline
\end{tabular}

Reaction conditions: [HIMBs] $\mathrm{HSO}_{4} /$ isobutene $=25 \%$ molar ratio, [HIMBs] $\mathrm{HSO}_{4}$ :Co-catalyst $=20: 1$ molar ratio, $140{ }^{\circ} \mathrm{C}, 8 \mathrm{~h}$, initial reaction pressure 2.0 $\mathrm{MPa}$, no additional solvent, catalysts: [HIMBs] $\mathrm{HSO}_{4}$ and co-catalyst (tricaprylylmethylammonium chloride).

${ }^{a}$ Conversion of olefin to form oligomers. 
Table 7

Structures of different light olefin oligomers synthesized in this study.

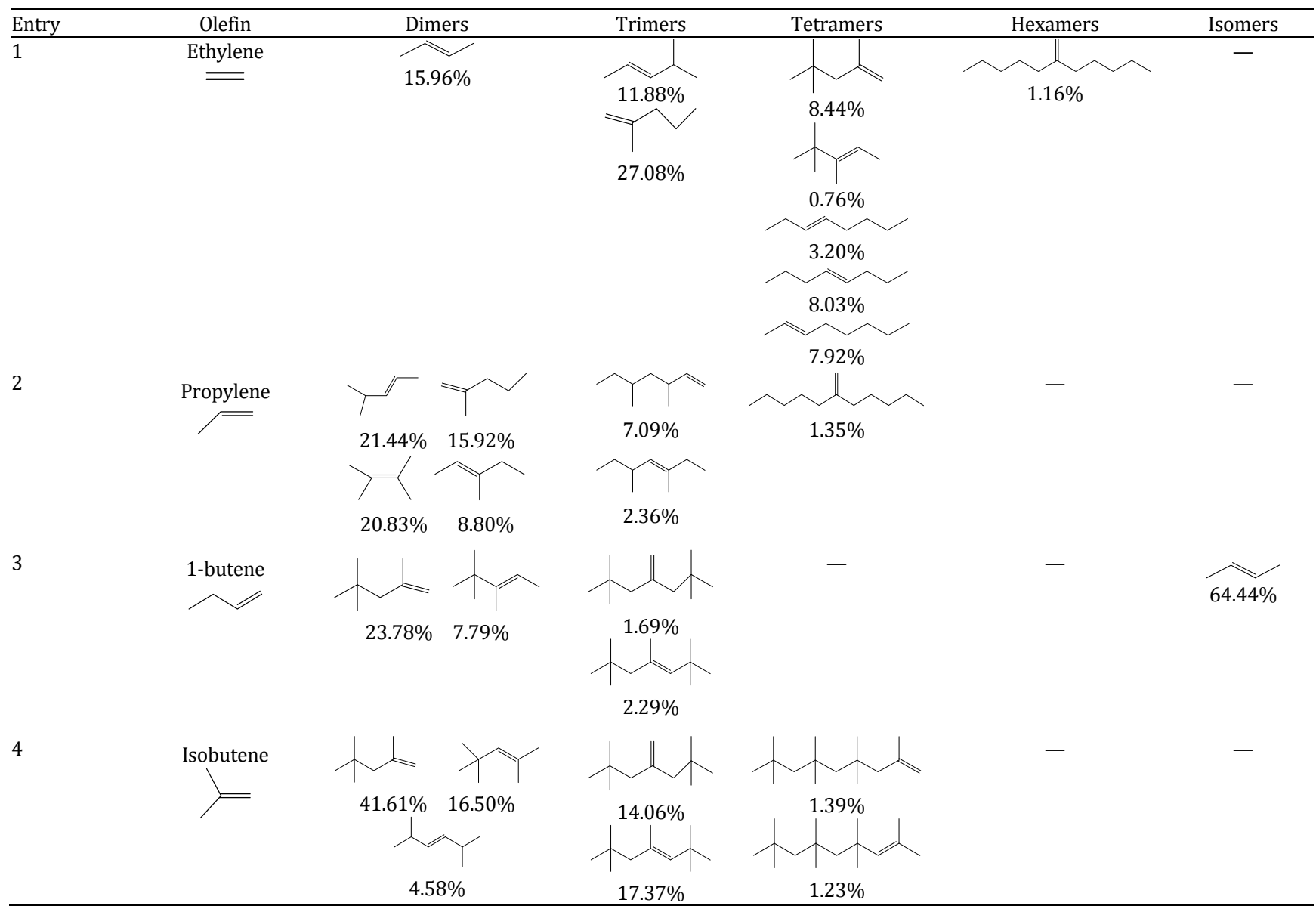

ophilic sites of isobutene. The second step is chain propagation, during which carbocations react with isobutene molecules; the carbocation chain length increases and new carbocations are produced. The last step is hydrogen transfer to generate different polymers. Moreover, oligomerization reactions are usu-

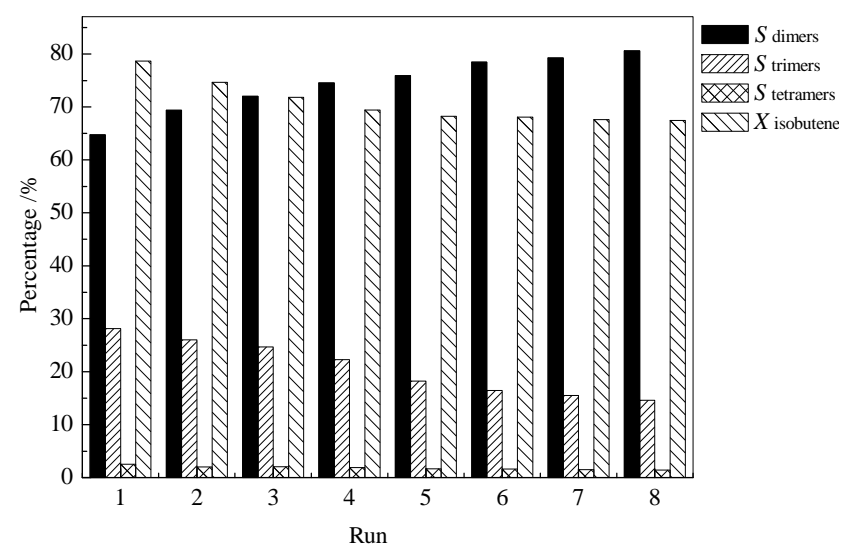

Fig. 6. Recycling experiments of the catalyst system. Reaction conditions: $[\mathrm{HIMBs}] \mathrm{HSO}_{4} /$ isobutene $=25 \%$ molar ratio, $[\mathrm{HIMBs}] \mathrm{HSO}_{4}$ : co-catalyst $=20: 1$ molar ratio, $140{ }^{\circ} \mathrm{C}, 8 \mathrm{~h}$, initial reaction pressure 2.0 $\mathrm{MPa}$, cyclohexane solvent, co-catalyst tricaprylylmethylammonium chloride. ally accompanied by double bond isomerization to produce some isomers. Analysis of the polymeric products can verify the validity of the mechanism postulated in this work. It is noted that olefin oligomerization via carbocation growth is a typical

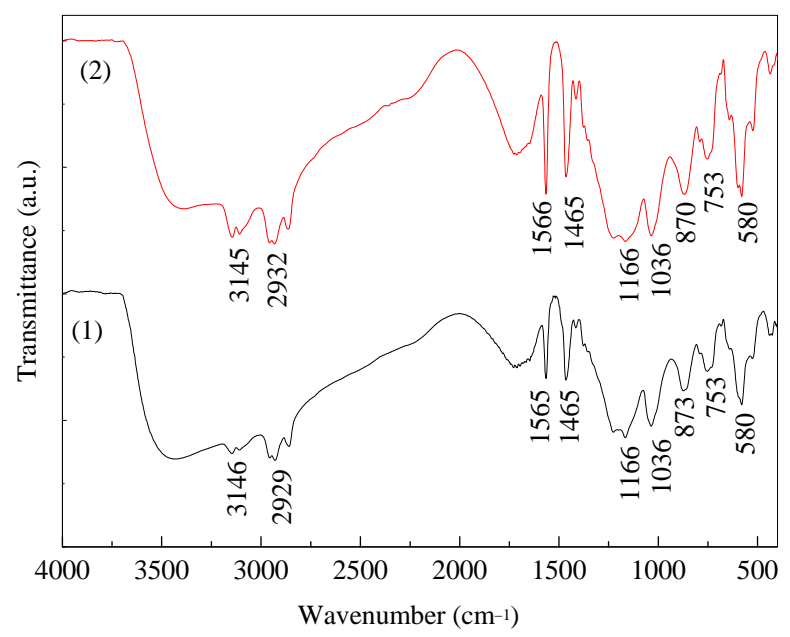

Fig. 7. FT-IR spectra of a fresh catalyst system ([HIMBs]HSO ${ }_{4}$ and co-catalyst tricaprylylmethylammonium chloride) and a catalyst system reused for eight runs. (1) Fresh catalyst system; (2) Catalyst system reused for eight runs (separation by layering). 

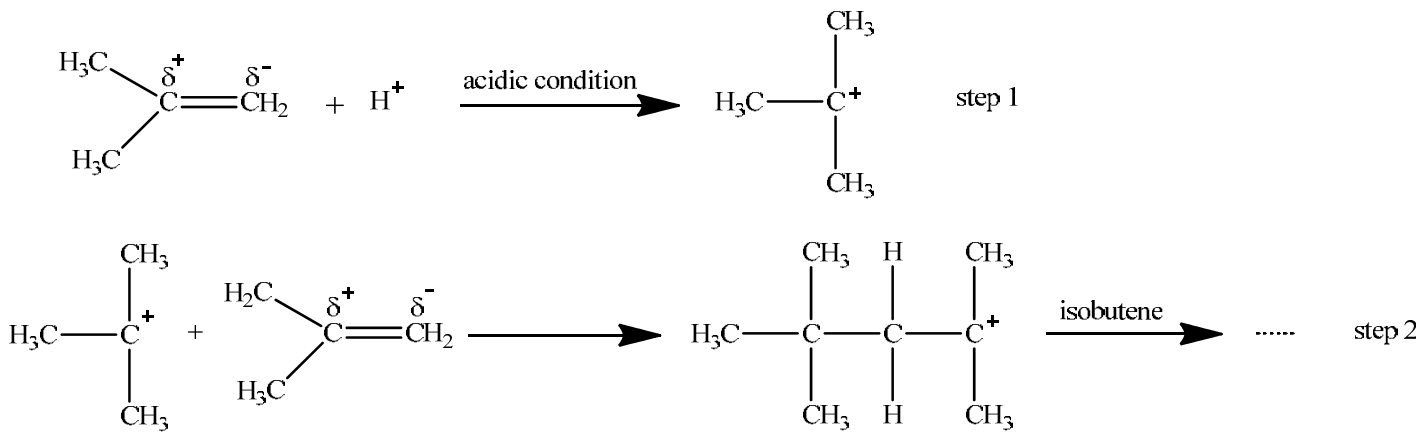<smiles>C=C(C)CC(C)(C)C</smiles><smiles>C=C(C)C(C(C)(C)C)C(C)(C)C</smiles>

$\alpha$-dimer<smiles>C=C(CCC(C)(C)C(C)(C)C)C(C)(C)C=CC(C)(C)C</smiles>

Scheme 2. A feasible reaction mechanism for isobutene oligomerization. This mechanism is constructed based on the product distribution [45].

acid-catalyzed reaction. Hence, catalysts with moderate acidity, such as those developed in this study $\left(-\mathrm{SO}_{3} \mathrm{H}\right.$ functionalized ILs and co-catalyst), may be appropriate for the oligomerization reaction.

\section{Conclusions}

Olefin oligomerization reaction catalyzed by a new and efficient catalyst system $\left(\mathrm{SO}_{3} \mathrm{H}\right.$-functionalized ionic liquids and co-catalyst) was investigated in this study. At the optimum conditions, the isobutene oligomerization reaction catalyzed by [HIMBs] $\mathrm{HSO}_{4}$ and co-catalyst (tricaprylylmethylammonium chloride) led to a high conversion and good selectivity of dimers, trimers, and tetramers $(83.12 \%, 52.02 \%, 35.80 \%$, and $3.14 \%$, respectively). The catalysts can be easily separated from the organic products by layering and can be used repeatedly without any further treatment. In addition, a plausible mechanism for the olefin oligomerization reaction has been proposed in this study. This study presents an effective and benign approach for olefin oligomerization to achieve high conversions and oligomer selectivity.

\section{References}

[1] J. Skupinska, Chem. Rev., 1991, 91, 613-648.

[2] D. S. McGuinness, Chem. Rev., 2011, 111, 2321-2341.

[3] A. Forestiere, H. Olivier-Bourbigou, L. Saussine, Oil Gas Sci. Technol., 2009, 64, 649-667.

[4] G. Gelbard, Ind. Eng. Chem. Res., 2005, 44, 8468-8498.

[5] V. N. Ipatieff, H. Pines, Ind. Eng. Chem., 1935, 27, 1364-1369.

[6] J. F. Knifton, J. R. Sanderson, P. E. Dai, Catal. Lett., 1994, 28, 223-230.

[7] A. G. Stepanov, M. V. Luzgin, V. N. Romannikov, K. I. Zamaraev, Catal. Lett., 1994, 24, 271-284.

[8] E. Krivan, S. Tomasek, J. Hancsok, Period Polytech. Chem. Eng., 


\section{Graphical Abstract}

Chin. J. Catal., 2018, 39: 1110-1120 doi: 10.1016/S1872-2067(18)63071-2

Olefin oligomerization via new and efficient Brönsted acidic ionic liquid catalyst systems

Guoqin Wang, Heyuan Song, Ruiyun Li, Zhen Li, Jing Chen *

Lanzhou Institute of Chemical Physics, Chinese Academy of Sciences; University of Chinese Academy of Sciences

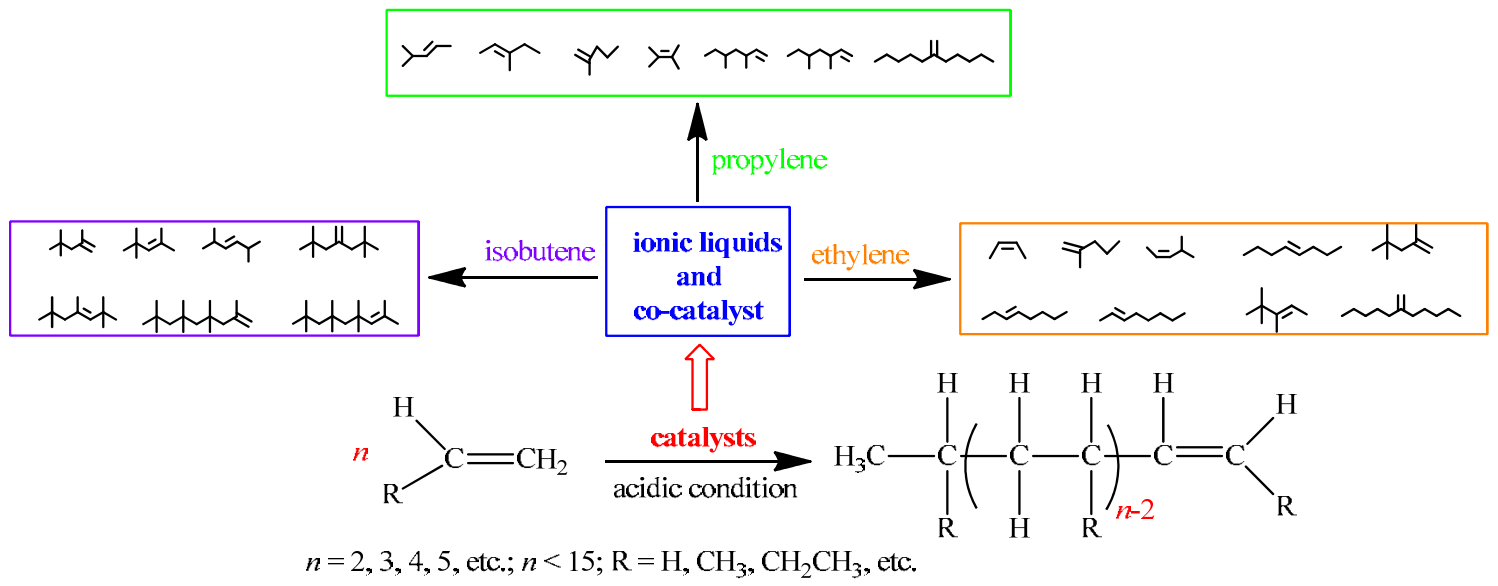

In this work, light olefin (ethylene, propylene, and isobutene) oligomerization was carried out using Brönsted-acidic ionic liquids and co-catalyst systems, which exhibit good catalytic activity. Further, the structures of the resultant oligomers and their selectivity were analyzed.

2014, 58, 149-156.

[9] S. M. Pillai, M. Ravindranathan, J. Chem. Soc., Chem. Commun., 1994, 1813-1814.

[10] B. M. Antunes, A. E. Rodrigues, Z. Lin, I. Portugal, C. M. Silva, Fuel Process. Technol., 2015, 138, 86-99.

[11] A. Behr, N. Rentmeister, T. Seidensticker, J. Vosberg, S. Peitz, D. Maschmeyer, Chem. Asian J., 2014, 9, 596-601.

[12] C. Carlini, M. Marchionna, A. M. Raspolli Galletti, G. Sbrana, Appl. Catal. A, 2001, 206, 1-12.

[13] R. Gao, W. H. Sun, C. Redshaw, Catal. Sci. Technol., 2013, 3, 1172-1179.

[14] P. Wasserscheid, M. Eichmann, Catal. Today, 2001, 66, 309-316.

[15] D. Thiele, R. Fernando de Souza, J. Mol. Catal. A, 2007, 264, 293-298.

[16] R. Fernando de Souza, B. C. Leal, M. Oberson de Souza, D. Thiele, J. Mol. Catal. A, 2007, 272, 6-10.

[17] A. G. Azizov, E. S. Kalbalieva, R. V. Alieva, N. R. Bektashi, B. M. Aliev, Petrol. Chem., 2010, 50, 56-64.

[18] J. P. Hallett, T. Welton, Chem. Rev., 2011, 111, 3508-3576.

[19] M. Petkovic, K. R. Seddon, L. P. N. Rebelo, C. S. Pereira, Chem. Soc. Rev., 2011, 40, 1383-1403.

[20] L. C. Player, B. Chan, P. Turner, A. F. Masters, T. Maschmeyer, Appl. Catal. B, 2018, 223, 228-233.

[21] D. Wang, F. Zhao, G. L. Zhu, C. G. Xia, Chem. Eng. J., 2018, 334, 2616-2624.

[22] Y. J. Fu, H. B. Yin, A. L. Wang, Y. H. Feng, L. Q. Shen, Ind. Eng. Chem. Res., 2015, 54, 6619-6626.

[23] W. G. Chen, H. B. Yin, Y. S. Zhang, Z. Z. Lu, A. L. Wang, Y. T. Shen, T. S. Jiang, L. B. Yu, J. Ind. Eng. Chem., 2010, 16, 800-804.

[24] X. Z. Liang, Ind. Eng. Chem. Res., 2013, 52, 6894-6900.

[25] X. Z. Liang, Energy, 2013, 63, 103-108.
[26] M. Goledzinowski, V. I. Birss, J. Galuszka, Ind. Eng. Chem. Res., 1993, 32, 1795-1797.

[27] O. Stenzel, R. Brull, U. M. Wahner, R. D. Sanderson, H. G. Raubenheimer, J. Mol. Catal. A, 2003, 192, 217-222.

[28] M. D. Ibragimova, F. I. Samedova, R. Z. Gasanova, N. G. Azmamedov, E. Z. Eivazov, Petrol. Chem., 2007, 47, 61-66.

[29] A. L. Wang, Y. Q. Jiang, W. G. Chen, H. B. Yin, Y. J. Liu, Y. T. Shen, T. S. Jiang, Z. N. Wu, J. Ind. Eng. Chem., 2012, 18, 237-242.

[30] Y. Q. Jiang, W. G. Chen, Y. J. Liu, H. B. Yin, Y. T. Shen, A. L. Wang, L. B. Yu, T. S. Jiang, Ind. Eng. Chem. Res., 2011, 50, 1893-1898.

[31] X. Y. Zhu, Y. J. Fu, H. B. Yin, A. L. Wang, X. X. Hou, Reac. Kinet. Mech. Catal., 2016, 118, 523-536.

[32] C. M. Gordon, Appl. Catal. A, 2001, 222, 101-117.

[33] Z. Y. Duan, Y. L. Gu, J. Zhang, L. Y. Zhu, Y. Q. Deng, J. Mol. Catal. A, 2006, 250, 163-168.

[34] A. C. Cole, J. L. Jensen, I. Ntai, K. L. T. Tran, K. J. Weaver, D. C. Forbes, J. H. Davis, J. Am. Chem. Soc., 2002, 124, 5962-5963.

[35] L. Q. Shen, H. B. Yin, A. L. Wang, X. F. Lu, C. H. Zhang, F. Chen, Y. T. Wang, H. J. Chen, J. Ind. Eng. Chem., 2014, 20, 759-766.

[36] D. C. Forbes, K. J. Weaver, J. Mol. Catal. A, 2004, 214, 129-132.

[37] Y. L. Gu, F. Shi, Y. Q. Deng, J. Mol. Catal. A, 2004, 212, 71-75.

[38] J. Z. Gui, X. H. Cong, D. Liu, X. T. Zhang, Z. D. Hu, Z. L. Sun, Catal. Commun., 2004, 5, 473-477.

[39] P. Bonhote, A. P. Dias, N. Papageorgiou, K. Kalyanasundaram, M. Gratzel, Inorg. Chem., 1996, 35, 1168-1178.

[40] W. Zhang, F. Han, J. Tong, C. G. Xia, J. H. Liu, Chin. J. Catal., 2017, 38, 805-812.

[41] X. Zhang, J. Zhong, J. W. Wang, J. K. Gao, A. S. Liu, Catal. Lett., 2008, 126, 388-395.

[42] J. S. Lee, J. W. Yoon, S. B. Halligudi, J. S. Chang, S. H. Jhung, Appl. Catal. A, 2009, 366, 299-303. 
[43] T. Patra, S. Ahamad, S. Upadhyayula, Appl. Catal. A, 2015, 506, 228-236.

[44] H. Y. Song, M. R. Kang, F. X. Jin, G. Q. Wang, Z. Li, J. Chen, Chin. J. Catal., 2017, 38, 853-861.
[45] Y. L. Gu, F. Shi, Y. Q. Deng, Catal. Commun., 2003, 4, 597-601.

[46] A. K. Kolah, Z. W. Qi, S. M. Mahajani, Chem. Innov., 2001, 31, 15-21.

[47] J. Z. Gui, H. Y. Ban, X. H. Cong, X. T. Zhang, Z. D. Hu, Z. L. Sun, J. Mol. Catal. A, 2005, 225, 27-31.

\title{
新型高效 Brönsted 酸性离子液体催化剂体系催化烯烃齐聚反应
}

\author{
王国芹 ${ }^{a, b}$, 宋河远 ${ }^{a, b}$, 李瑞云 ${ }^{a, b}$, 李 臻 ${ }^{a}$, 陈 静 ${ }^{a, *}$ \\ a 中国科学院兰州化学物理研究所羰基合成与选择氧化国家重点实验室, 甘肃兰州 730000 \\ $\mathrm{b}$ 中国科学院大学, 北京 100049
}

\begin{abstract}
摘要: 烯烃齐聚是重要的化工反应之一, 是指低碳烯烃在催化剂存在下发生聚合反应, 生成一个或多个单体重复相连的化 合物过程. 烯烃齐聚反应是一种碳链增长过程, 是生成线性 $\alpha$-烯烃的重要过程. 齐聚反应主要生成单体的二聚、三聚、四 聚或五聚物等低聚体, 发生反应的单体主要是低碳烯烃如乙烯、丙烯、正丁烯和异丁烯等. 烯烃齐聚产物应用十分广泛, 可 以用于合成环境友好的液体燃料、长链烷烃润滑油、表面活性剂、增塑剂、汽油柴油添加剂等重要化工产品, 同时齐聚产 物本身亦是重要的化工中间体和化学试剂. 烯烃齐聚反应研究的重点内容是开发新颖高效的催化剂, 以满足不同需要, 而 应用 Brönsted 酸性功能化离子液体作为催化剂用于齐聚反应的报道较少.

本文考察了新型高效催化剂体系 (Brönsted 酸性离子液体作为主催化剂, 三辛基甲基氯化铵作为助剂) 对烯烃齐聚反 应的催化性能. 合成的 Brönsted 酸性离子液体通过红外光谱、紫外可见光谱、 ${ }^{1} \mathrm{H}$ 核磁共振和 ${ }^{13} \mathrm{C}$ 核磁共振等进行系列表征, 并进一步分析其结构与酸度的关系. 结果表明, 在相同的反应条件下, Brönsted 酸性离子液体 [HIMBs] $\mathrm{HSO}_{4}$ 对烯烃齐聚反 应具有最好的催化活性. 本文考察了不同离子液体、离子液体用量、不同助剂、助剂用量、反应时间、反应压力、反应

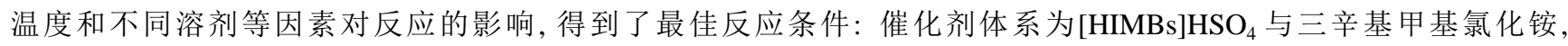
[HIMBs] $\mathrm{HSO}_{4} /$ 异丁烯摩尔比为 $25 \%$, [HIMBs] $\mathrm{HSO}_{4} /$ 助剂 (三辛基甲基氯化铵)摩尔比为 $20: 1,140{ }^{\circ} \mathrm{C}, 8 \mathrm{~h}$, 反应起始压力为 $2.0 \mathrm{MPa}$, 无添加溶剂 (离子液体本身作催化剂和溶剂). 在最佳反应条件下对反应物进行了拓展, 并研究了催化剂体系的循 环使用情况. 在最佳反应条件下, 异丁烯齐聚反应中反应物转化率为 $83.21 \%$, 三聚物选择性高达 $35.80 \%$, 二聚物选择性为 $52.02 \%$, 四聚物选择性为 $3.14 \%$. 结果表明, 本文提出的催化剂体系对烯烃齐聚反应具有较好的催化性能. 同时, 催化剂体 系可以通过静置分层与产物分离, 并进行循环使用. 根据以往的报道和反应产物分布, 推测了烯烃齐聚反应机理. 烯烃齐 聚反应为酸催化反应, 生成碳正离子中间体进行碳链增长, 生成齐聚产物.
\end{abstract}

关键词: Brönsted 酸性离子液体; 烯烃; 齐聚反应; 催化反应; 共催化剂

收稿日期: 2017-12-28. 接受日期: 2018-04-11. 出版日期: 2018-06-05.

*通讯联系人. 电话: (0931)4968068; 传真: (0931)4968129; 电子信箱: chenj@licp.cas.cn

基金来源：国家自然科学基金 (21473225).

本文的电子版全文由Elsevier出版社在ScienceDirect上出版(http://www.sciencedirect.com/science/journal/18722067). 